\title{
ANALISIS PERILAKU KONSUMEN BERDASARKAN TIPE KEPRIBADIAN PADA BISNIS ONLINE SELAMA PANDEMI
}

\author{
Maemunah ${ }^{1}$, Dedi Rianto Rahadi ${ }^{2}$ \\ President University, Indonesia
}

Corresponding Author:

Nama Penulis: Maemunah

E-mail: marisamaemunah@gmail.com

\begin{abstract}
:
Consumers are the most important factor in business. Every consumer has a different personality. Personality type is one of the factors that influence consumer behavior, especially in online businesses. Many new online businesses have sprung up in Indonesia during the pandemic. The pandemic has closed several places where people need it, so that many people turn to online businesses. The rise of online businesses makes it easier for consumers to fulfill the desired product or service. This study aims to analyze consumer behavior based on their personality in online businesses during the pandemic. The research method used is a qualitative method. The author distributes questionnaires to 40 students throughout Indonesia and conducts interviews. Based on the research results, it can be concluded that 1) The number of consumers in online businesses tends to increase during the pandemic; 2) Online businesses influence consumer behavior based on their personality during a pandemic; 3) There are different processes online businesses influence consumer behavior based on their personality during a pandemic.
\end{abstract}

Keywords: personality type, consumer behavior, online business

\begin{abstract}
Abstrak:
Konsumen adalah faktor terpenting dalam bisnis. Setiap konsumen memiliki kepribadian yang berbeda. Tipe kepribadian merupakan salah satu faktor yang mempengaruhi perilaku konsumen, khususnya dalam bisnis online. Banyak bisnis online baru yang bermunculan di Indonesia selama pandemi. Pandemi telah menutup beberapa tempat di mana masyarakat membutuhkannya, sehingga masyarakat banyak beralih ke bisnis online. Maraknya bisnis online ini semakin memudahkan konsumen dalam memenuhi produk atau jasa yang diinginkan. Penelitian ini bertujuan untuk menganalisis perilaku konsumen berdasarkan kepribadiannya pada bisnis online selama pandemi. Metode penelitian yang digunakan adalah metode kualitatif. Penulis menyebarkan kuesioner kepada 40 mahasiswa di seluruh Indonesia dan melakukan wawancara. Berdasarkan hasil penelitian dapat disimpulkan, yaitu 1) Jumlah konsumen pada bisnis online cenderung meningkat selama pandemi; 2)Bisnis online mempengaruhi perilaku konsumen berdasarkan kepribadiannya selama pandemi ; 3)Terdapat proses yang berbeda-beda bisnis online mempengaruhi perilaku konsumen berdasarkan kepribadiannya selama pandemi
\end{abstract}

Kata kunci: tipe kepribadian, perilaku konsumen, bisnis online 


\section{PENDAHULUAN}

Di Indonesia mengalami perkembangan teknologi dan informasi yang semakin pesat saat ini. Perkembangannya terlihat dengan semakin meningkatnya penggunaan internet oleh masyarakat. Kementerian Komunikasi dan Informatika (Kemenkominfo) mengungkapkan bahwa saat ini pengguna internet di Indonesia mencapai 63 juta orang. Berdasarkan angka tersebut, 95 persennya menggunakan internet untuk mengakses jejaring sosial. Selain itu, peningkatan penggunaan smartphone juga semakin meningkat dengan adanya pandemi Covid-19. Adanya pandemi Covid-19 telah mengubah kebiasaan masyarakat dalam menjalani aktivitas sehari-hari. Masyarakat menjadi lebih sering menggunakan internet untuk mengurangi interaksi secara langsung dengan orang banyak yang dapat menularkan Covid-19.

Keberadaan internet saat pandemi ini memudahkan masyarakat dalam berkomunikasi dan mendapatkan segala macam informasi dan kebutuhan yang mereka butuhkan. Peran internet pada masyarakat digunakan sebagai sarana komunikasi yang praktis karena dapat berinteraksi dengan orang lain tanpa terhalang jarak dan waktu. Internet digunakan masyarakat agar mereka tetap beraktivitas dan bersosialisasi pada saat pandemi ini. Dengan internet, masyarakat tidak perlu datang ke tempat keramaian untuk membeli kebutuhannya. Masyarakat cukup dengan memesannya secara online dan menunggunya di rumah saja. Dengan demikian, internet digunakan sebagai sarana bisnis untuk memenuhi kebutuhan masyarakat.

Setiap masyarakat untuk menyelaraskan kehidupannya, memiliki kebutuhan dan keinginan yang harus terpenuhi. Upaya untuk memenuhi kebutuhan dan keinginannya salah satunya dengan berbelanja. Belanja adalah aktivitas atau kegiatan dengan wujud membeli barang atau jasa. Pola perilaku konsumen dalam berbelanja kebanyakan dibangkitkan oleh ketidakmampuan konsumen dalam mengendalikan dorongan-dorongan untuk membeli. Dorongan keinginan berbelanja tersebut dapat terpenuhi dengan berbagai cara baik dengan konvensional maupun secara online melalu internet.

Berbelanja secara konvensional telah umum dikenal masyarakat yaitu 
Vol. 1 No. 12020

konsumen berbelanja dengan mendatangi secara langsung tempat perbelanjaan untuk membeli barang atau jasa yang mereka butuhkan dan inginkan dengan sistem pembayaran yang dilakukan saat itu juga. Didalam prosesnya, terjadi interaksi secara langsung antara penjual dengan konsumen. Sedangkan masa pandemi ini, masyarakat harus mengurangi interaksi secara langsung satu sama lain. Maka dari itu, masyarakat berbelanja melalui internet secara online yang lebih praktis.

Dengan semakin banyaknya masyarakat menggunakan internet untuk berbelanja, maka banyak pebisnis menggunakan peluang ini untuk memenuhi kebutuhan masyarakat. Digital platform digunakan pemain bisnis untuk menjadi strategi bisnis dalam menghadapi Covid-19 ini. Pemain bisnis beradaptasi dengan cepat dalam menanggapi situasi ini. Pemain bisnis mulai menyesuaikan pengelolaan pesan dan pendekatan kreatif supaya relevan dengan kondisi yang dihadapi konsumen. Pemain bisnis benar-benar mempersiapkan aktivitas jual beli dari offline ke online.

Selain pemain bisnis, banyak juga masyarakat biasa yang membangun bisnis online. Dalam Kamus Besar Bahasa Indonesia(KBBI), bisnis online adalah suatu usaha komersial dalam bidang penjualan produk dan jasa yang memanfaatkan wada internet. Menurut Yudhi Wicaksono, bisnis online merupakan sarana jual beli melalui internet dengan menggunakan fitur-fitur yang telah disediakan. Dari pernyataan diatas maka dapat ditarik kesimpulan bahwa bisnis online adalah kegiatan individu atau kelompok yang melalukan proses pemasaran,jual beli dan transaksi dengan perantara jaringan internet.

Bisnis online dijadikan sasaran konsumen untuk memenuhi kebutuhan sehari-harinya selama pandemi ini. Konsumen memilih secara online dalam berbelanja seperti vitamin, obat-obatan, snack,peralatan rumah tangga dan lain sebagainya. Konsumen dapat memenuhi kebutuhannya dengan mudah seperti melalui shopee, toko pedia, lazada, go food, dan aplikasi lainnya.

Tipe kepribadian konsumen perlu diperhatikan oleh para pebisnis. Ghufron dan Risnawati (2010) menjelaskan terkait kepribadian bahwa masingmasing individu memiliki cara yang berbeda dalam 
Vol. 1 No. 12020

berperasaan,mengembangkan pemikiran-pemikirannya dan menentukan minat pribadinya, hal ini berhubungan dengan setiap individu berbeda dalam mengolah dan bereaksi terhadap berbagai kebutuhannya. Kepribadian merupakan aspek psikologi yang penting dalam menentukan perilaku konsumen. Perbedaan kepribadian pada setiap individu menghasilkan persepsi yang berbeda dalam berperilaku saat menjadi konsumen.

Konsumen memiliki ragam tipe kepribadian yang berbeda-beda menjadi hal yang sangat perlu diperhatikan. Berdasarkan hasil penelitian Atikah Hadyan(2018) mengenai "Pengaruh Tipe Kepribadian Terhadap Impulsive Buying Pada Mahasiswi Psikologi Universitas Esa Unggul Yang Melakukan Pembelian Secara Online Shopping", menunjukkan bahwa salah satu faktor yang mempengaruhi perilaku impulsive buying adalah tipe kepribadian. Hal ini menjelaskan bahwa tipe kepribadian konsumen merupakan salah satu faktor yang mempengaruhi perilaku konsumen. Salah satu teori yang digunakan untuk mengambarkan kepribadian seseorang dalah big five personality yang dikembangkan oleh McCrae dan Costa. McCrae dan Costa mengelompokkan model kepribadian menjadi lima kelompok dimensi yaitu agreeableness, conscientiousness, ekstraversion, neuroticism, dan openness to experience.

The Big Five Personality yang dikemukakan oleh McCrae \& Costa adalah sebagai berikut:

1. Agreeableness menggambarkan individu yang memiliki kepercayaan kepada orang lain. Kepercayaan yang dimiliki tersebut, membuat individu tipe ini cenderung kooperatif dan juga tunduk kepada orang lain . maksud dari tunduk disini ialah individu tersebut mampu patuh pada individu lain telah ia percaya. Dimensi ini juga menggambarkan individu yang cenderung ikut-ikutan dan mudah mengalah. Tidak hanya itu, Orang yang ramah dan bersahabat termasuk pada tipe ini. Orang yang memiliki skor rendah pada tipe ini akan menunjukkan sifat negatif yang dimilikinya yakni rasa kecurigaan dan suka bermusuhan .

2. Conscientiousness menggambarkan individu yang memiliki kedisiplin pada dirinya. Kemampuan dalam mengatur waktu menggambarkan 
kedisiplinan tersebut lalu diperkuat dengat ambisi dan keinginan bekerja. . Dari ambisi dan keinginan tersebut, tipe ini cenderung berorientasi pada prestasiprestasi. Sebaliknya, orang yang memiliki skor rendah pada tipe ini akan muncul sifat negatif yakni kurang memiliki motivasi sehingga mudah menyerah dan menjurus tidak memiliki tujuan. Dengan demikian, maka menyebabkan individu tipe ini cenderung malas, tak teratur dan sering terlambat. Friedman(2006) menjelaskan, individu tipe conscientiousness rendah biasanya mudah teralih perhatiannya, tak dapat diandalkan, berantakan dan tak terarah serta ceroboh.

3. Extraversion menggambarkan individu yang memiliki daya tarik pada hubungan interpersonal. Daya tarik ini menyebabkan individu cenderung mudah bergaul dan memiliki kemampuan untuk menunjukkan kasih sayangnya pada individunya lain. Individu tipe extraversion dengan skor tinggi cenderung penuh semangat, antusias, dominan, ramah dan komunikatif. Sedangkan, individu dengan skor rendah pada tipe ini adalah cenderung lebih pendiam, sering menyendiri, dan serius.

4. Neuroticism menggambarkan kestabilan dan ketidakstabilan emosi setiap individu. Individu yang memiliki skor tinggi pada tipe ini menjurus mudah cemas, impulsif,rentan dalam menghadapi dan emosional. Kebalikannya, individu yang memiliki skor rendah pada tipe ini cenderung memiliki emosional positif yang stabil dan terlihat lebih tenang.

5. Openness to experience menurut Friedman (2006) adalah orang yang imajinatif, kreatif, dan artistik. Dengan sifat ini, membuat individu cenderung penasaran akan hal baru dan memiliki pemikiran yang imajinatif. Sebaliknya, sifat yang dimiliki oleh individu dengan openess yang rendah cenderung realistis, tidak suka perubahan dan konservatif.

Berdasarkan paparan mengenai bige five diatas, tipe kepribadian big five dirasa lebih mampu menyempurnakan tipe kepribadian lainnya seperti introvert dan ekstrovert. Sehingga dengan demikian pendekatan big five personality mampu lebih banyak mengungkapkan perilaku konsumen berdasarkan dimensi yang dimilikinya. 
Kotler (2005:183) memaparkan perilaku konsumen adalah suatu proses menilai dan memilih dari bermacam-macam alternatif yang sesuai dengan kepentingan-kepentingan tertentu dengan memutuskan sebuah pilihan yang dianggap paling menguntungkan.

Sedangkan menurut Swasta \& Handoko (2008 : 10) perilaku konsumen adalah beragam kegiatan individu yang secara langsung terlibat dalam proses mendapatkan dan menggunakan barang atau jasa melalui proses pengambilan keputusan dan penentuan pada kegiatan tersebut. Terdapat dua poin penting dari dua pengertian diatas yakni proses pengambilan keputusan dan kegiatan fisik yang digunakan untuk menilai, mendapatkan, dan mempergunakan berbagai barang dan jasa ekonomis.

Terdapat banyak faktor yang mempengaruhi perilaku konsumen dalam pembelian suatu produk. Menurut Suharno dan Sutarso (2014:6) perilaku konsumen dipengaruhi oleh empat faktor yaitu budaya, sosial, pribadi dan psikologi. Budaya menyangkut semua aspek kehidupan masyarakat sehingga menjadi faktor penentu yang paling mendasar pada perilaku konsumen.

Didalam budaya juga ada sub-budaya yang terdiri dari daerah geografis, agama, kebangsaan, kelompok ras. Selain faktor budaya, kelompok acuan, keluarga, status dan peran seseorang pada faktor sosial juga hal yang mempengaruhi perilaku konsumen. Selanjutnya faktor pribadi juga mempengaruhi perilaku konsumen. Kepribadian akan turut mengambil andil dalam proses pembelian. Faktor yang terakhir adalah faktor psikologi seperti motivasi, persepsi, pembelajaran, keyakinan serta pendirian.

Dari beberapa telaah studi yang telah dipaparkan, maka peneliti tertarik untuk menganalisis kepribadian konsumen dengan pendekatan big five personality dalam berperilaku pada bisnis online selama pandemi. Dengan demikian, peneliti termotivasi untuk mengambil judul "Analisis tipe kepribadian konsumen pada bisnis online selama pandemi “. 


\section{METODE PENELITIAN}

Penelitian ini penulis menggunakan metode penelitian kualitatif . Sejalur dengan yang dipaparkan Moeloeng(2000:3), penelitian kualitatif adalah prosedur penelitian yang membuahkan hasil data deskriptif berupa uraian kata yang tertulis atau lisan dari banyak orang dan perilaku yang diamati. Untuk menghasilkan data, peneliti menggunakan metode wawancara dan penyebaran kuesioner. Responden penelitian ini adalah 40 mahasiswa yang berada di seluruh indonesia. Respon dari 40 mahasiswa ini yang dijadikan kesimpulan oleh peneliti.

\section{HASIL PENELITIAN}

Berdasarkan penelitian dengan penyebaran kuesioner kepada 40 responden mahasiswa, diperoleh hasil sebegai berikut:

1. Karakteristik responden

- Jenis kelamin

Laki-laki berjumlah 3 responden

Perempuan berjumlah 37responden

- Usia

Usia 15-25 tahun berjumlah 38 responden

Usia 26-35 tahun berjumlah 2 responden

2. Tipe kepribadian responden

- Extraversion berjumlah 16 responden

- Agreeableness berjumlah 12 responden

- Openess to experience berjumlah 8 responden

- Neuroticism berjumlah 4 responden

3. Berdasarkan hasil analisis dari 40 responden, terdapat 23 responden yang suka belanja online, 14 responden yang suka sekali dengan belanja online dan 3 responden yang tidak suka belanja online.

4. Beragam alasan konsumen mengapa suka dan tidak suka belanja online selama pandemi.

5. Berdasarkan hasil analisis dari 40 responden, terdapat 36 responden yang 
menjawab Ya bahwa bisnis online selama pandemi mempengaruhi perilakunya berdasarkan kepribadian dan 4 responden yang menjawab tidak.

6. Persentase bisnis online selama pandemi mempengaruhi perilaku responden berdasarkan tipe kepribadiannya

- $\quad 0-20 \%$ berjumlah 13

- $20-40 \%$ berjumlah 11

- $40-60 \%$ berjumlah 10

- $60-80 \%$ berjumlah 5

- $\quad 80-100 \%$ berjumlah 1

7. Beragam respon mengenai proses bisnis online selama pandemi mempengaruhi perilaku konsumen berdasarkan kepribadiannya.

\section{PEMBAHASAN}

Berdasarkan pemaparan hasil penelitian diatas menunjukkan sebanyak 37 responden yang suka belanja online dan 3 responden yang tidak suka belanja online selama pandemi ini. Hasil temuan ini juga menjelaskan alasan mengapa mereka menyukai dan tidak menyukai belanja online selama pandemi. Berdasarkan alasan responden yang menyukai belanja online selama pandemi ini, belanja online menjadi solusi di saat pandemi karena harus di rumah saja dan tidak kemana-mana. Responden merasa sangat terbantu dengan adanya bisnis online karena segala kebutuhan dapat terpenuhi dengan mudah dan tetap di rumah saja .

Responden hanya perlu memesan produk atau jasa yang diinginkan secara online di rumah lalu pesanan akan diantar ke rumah dengan baik. Menurut pendapat responden, belanja online mampu mempersingkat waktu dan tidak membuang tenaga untuk berbelanja. Belanja online menurut responden juga banyak produk yang harganya lebih murah dibandingkan belanja secara konvensional. Responden juga menyampaikan bahwa belanja online mampu membatasi interaksi secara langsung dengan orang lain dan mengurangi kerumunan. Responden yang mengatakan tidak suka belanja 
Vol. 1 No. 12020

online selama pandemi memiliki alasan karena mereka tidak memiliki banyak uang untuk berbelanja.

Berdasarkan hasil penelitian menunjukkan bahwa setiap responden memiliki kepribadian yang berbeda-beda. Dengan perbedaan tersebut, terdapat responden yang terpengaruhi dan tidak terpengaruhi kepribadiannya oleh bisnis online selama pandemi ini. responden dengan kepribadian Agreeableness menggambarkan responden yang memiliki kepercayaan kepada orang lain, mudah beradaptasi dengan lingkungannya sehingga kooperatif.

Tipe ini mengindikasikan seseorang yang mudah mengalah, cenderung ikut-ikutan, ramah dan bersahabat. Orang yang memiliki skor rendah pada tipe ini akan menunjukkan sifat negatif yang dimilikinya yakni adanya perasaan yang penuh kecurigaan dan suka bermusuhan. Dari kepribadian tipe ini, terdapat proses tersendiri bagaimana bisnis online mempengaruhinya. Penggunaan smartphone selama pandemi menyebabkan responden sering melihat influencer, iklan, aplikasi e-commerce yang mempromosikan beragam produk atau jasa.

Responden tipe ini menjadi ikut-ikutan menggunakan produk atau jasa karena mereka melihat review yang nyata oleh influencer yang mereka suka. Review ini yang menyebabkan mereka percaya dan ingin mencoba sebuah produk atau jasa. Dengan demikian,responden tipe ini menjadi sering belanja online bukan faktor butuh tetapi karena terpengaruh influencer, iklan dan promosi dari luar. Jika responden tipe ini merasa puas pasca belanja online, maka responden ini percaya dengan bisnis online tersebut. Dengan demikian, responden tipe ini akan semakin sering membeli produk atau jasa pada bisnis online tersebut.

Sedangkan extraversion menggambarkan konsumen yang mampu menjalin hubungan interpersonal dengan baik. Tipe ini cenderung mudah bergaul dan memiliki kemampuan untuk menunjukkan kasih sayangnya pada individunya lain. Individu tipe extraversion dengan skor tinggi cenderung penuh semangat, antusias, dominan, ramah dan komunikatif. Sedangkan, 
Vol. 1 No. 12020

individu dengan skor rendah pada tipe ini cenderung lebih pendiam, sering menyendiri, dan serius. Berdasarkan hasil penelitian, responden ini mengaku bahwa selama pandemi ini terdapat peningkatan semangat dan hawa nafsu untuk terus belanja online selama di rumah saja. Sifat yang mudah bergaul menyebabkan responden sangat mengikuti tren terutama pada fashion dan kecantikan.

Responden menyatakan bahwa selama pandemi ini banyak sekali bermunculan fashion dan produk kecantikan yang baru dan unik sehingga membuat mereka tertarik untuk membelinya. Responden tipe ini merasa bahwa selama pandemi banyak masyarakat yang di PHK lalu beralih ke bisnis online untuk memenuhi kehidupannya. Dengan demikian, mereka ingin membantu pedagang online yang kesulitan mencari pendapatan selama pandemi ini.

Disisi lain, neuroticism menggambarkan konsumen yang emosional, rentan dalam menghadapi segala hal, impulsif, dan pencemas. Sebaliknya, konsumen yang memiliki skor rendah pada tipe ini cenderung lebih tenang serta mempunyai kemantapan emosional yang positif. Adanya covid-19 membuat responden tipe ini merasa cemas sehingga selama pandemi ini mereka berusaha membeli sebuah produk atau jasa secara online. Mereka memikirkan resiko jika berbelanja secara offline sehingga belanja online menjadi pilihan mereka. Rangsangan oleh pebisnis online seperti review oleh influencer mengenai barang yang estetik dan unik, diskon, buy 1 get 1 , gratis ongkir di media sosial dan aplikasi e-commerce membuat sifat impulsif mereka tertarik untuk belanja online selama pandemi.

Openness to experience menurut Friedman (2006) adalah orang yang imajinatif, kreatif, dan artistik. Dengan sifat ini, membuat konsumen cenderung penasaran akan hal baru dan memiliki pemikiran yang imajinatif. Sebaliknya, sifat yang dimiliki oleh individu dengan openess yang rendah cenderung realistis, tidak suka perubahan dan konservatif. Berdasarkan hasil penelitian ini, responden mengatakan bahwa banyak produk baru yang ditawarkan secara online selama pandemi ini sehingga membuat mereka penasaran untuk 
mencobanya.

Responden memutuskan membeli sebuah produk tanpa memikirkan kembali apakah produk itu berguna atau tidak karena mereka hanya penasaran untuk mencoba produk itu. Kekreatifan pada responden tipe ini menyebabkan mereka yang awalnya menjadi konsumen lalu berkreasi untuk menjual sebuah produk juga. Mereka mengkreasikan sebuah produk untuk dijual lagi dengan cara seperti re-packing yang menarik dan mengubah kaos polos menjadi tie dye.

Dengan paparan tersebut, sangat terlihat bahwa terjadi peningkatan jumlah konsumen pada bisnis online selama pandemi. Peningkatan ini terjadi karena perubahan belanja dari offline ke online. Proses bisnis online mempengaruhi perilaku konsumen berdasarkan kepribadiannya pun berbedabeda.

\section{KESIMPULAN}

Berdasarkan hasil penelitian dapat disimpulkan bahwa:

- Jumlah konsumen pada bisnis online cenderung meningkat selama pandemi

- Bisnis online mempengaruhi perilaku konsumen berdasarkan kepribadiannya selama pandemi

- Terdapat proses yang berbeda-beda bisnis online mempengaruhi perilaku konsumen berdasarkan kepribadiannya selama pandemi

\section{REFERENSI}

Antasari, D. A. 2020. Pengaruh Uang Elektronik Terhadap Keputusan Pembelian (Studi Kasus di Kota Kediri). Jurnal Manajemen Vol 10.Pp. 8-15.

Astutik, P. P., Chusniyah, T., Viatrie, D. I. 2020. Kepribadian Big Five Terhadap Impulsive Buying Behavior pada Mahasiswi Fakultas Ekonomi dan Bisnis. Journal An-Nafs: Kajian Penelitian Psikologi Vol. 5.

Goenadhi, L. 2011. Faktor-Faktor yang Mempengaruhi Perilaku Konsumen dalam Keputusan Pembelian Mobil Toyota Avanza di Kota Banjarmasin. Jurnal Manajemen dan Akuntansi Vol. 12. 
Gumelar, G., Pandina, I. 2014. Trait Kepribadian dan Kepercayaan Konsumen untuk Berbelanja pada Toko Online. Jurnal Perspektif Ilmu Pendidikan Vol. 25.Pp 75-81.

Hadyan, A., Mariyanti, S., Safitri, M. 2018. Pengaruh Tipe Kepribadian terhadap Impulsive Buying pada Mahasisa Psikologi Universitas Esa Unggul yang Melakukan Pembelian Secara Online Shopping. Jurnal Psikologi Universitas Esa Unggul. Hanum, Z., Hidayat, S. 2017. Faktor-Faktor yang Mempengaruhi Peilaku Konsumen dalam Keputusan Pembelian Sepatu Merek Nike di Kota Medan. Jurnal Bisnis Administrasi Vol. 06(1).Pp. 3743.

Iskandar, L. M., Zulkarnain. 2013. Penyesalan Pasca Pembelian Ditinjau dari Big Five Personality. Jurnal Psikologi Vol. 40.

Prasetiya, A., Ihsani, R. K. 2020. The Big Five Personality dengan Minat Beli Gamis pada Mahasiswi yang dimoderatori oleh Persepsi terhadap Kualitas Produk. Psyche 165 Journal, Vol. 13 (1).Pp. 107-113.

https://kominfo.go.id/index.php/content/detail/3415/Kominfo+\%3A+Pengg una+Internet+di+Indonesia+63+Juta+0rang/0/berita satker

http://eprints.umm.ac.id/30158/2/jiptummpp-gdl-annisayunn-29655-2babi.pdf

https://www.rapikan.com/pengertian-bisnis-online-dan-jenisnya/

https://id.m.wikipedia.org/wiki/Kepribadian_Big_Five

https://media.neliti.com/media/publications/103179-ID-pengaruh-faktorbudaya-sosial-pribadi-da.pdf 